\title{
THE IMPACT GENERATED BY SARS-COV-2 VIRUS ON THE AIR QUALITY IN THE CONSTANTA PORT AREA
}

\author{
Vasile RAȚĂ, Angela IVAN, Liliana RUSU \\ "Dunarea de Jos" University, Galati, ROMANIA \\ vasile.rata@ugal.ro; angela.ivan@ugal.ro; liliana.rusu@ugal.ro
}

\begin{abstract}
The effect that the shipping industry has on the air quality in the areas adjacent to the ports, where it carries out loading and unloading operations, it is already known. In the new global context generated by the spread of the SARS-CoV-2 virus, the economy was affected. Due to the measures that many states have taken to limit the spread of this virus among people, the production activity has been stopped in many economic sectors and consequently, the freight industry by sea has also been affected. Measures that have been taken in the navigable sector in Romania are known, but also worldwide. In the perspective of reducing the density of ships in ports, the evolution of some parameters of air quality in the area of Constanta County will be followed. This evolution will be correlated with the evolution of the volume of port calls of international ships to the port services in the port of Constanta and presented in this study.
\end{abstract}

Keywords: air emissions, air quality, COVID-19, port of Constanta, shipping

\section{INTRODUCTION}

The subject of emissions from shipping is a long debate in many scientific groups and beyond. The controversy of this subject arises from the need to transport goods by water, due to the proven efficiency in terms of unit of fuel consumed per ton of goods transported over a limited distance, for example per kilometre. The kilometre was mentioned, although in the maritime field the nautical mile is used for distance definition, because there is always the comparison with the terrestrial type transport: road or railway transport. Under these conditions, however, it would be assumed that shipping pollutes less than road transport, for example. This hypothesis is partially true; indeed, the volume of $\mathrm{CO} 2$ produced by shipping per tonne $\mathrm{km}$ represents almost $20 \%$ of that produced by road transport in some studies [1] or even $10 \%$ in other studies [2]. On the other hand, in the case of NOx and PM emissions, they are quite similar, instead $\mathrm{SO} 2$ emissions that are a highlight for shipping as compared to other areas of transport. This is due to the fact that the shipping industry uses fuels of a lower quality, cheaper, but which have a significant saturation of sulphur.
This study aims to determine the impact of shipping on air quality in the area adjacent to the port of Constanta, in terms of measures imposed by the Romanian Government to reduce the spread of SARS$\mathrm{CoV}-2$ virus in Romania. In Romania, the state of emergency was officially declared by Military Ordinance, issued by The Ministry of the Internal Affairs, which was enforced starting with 18 March. In the period between start and the end of the state of emergency were enforce a couple of Military Ordinance issued by The Ministry of the Internal Affairs, which had described a series of restrictions and procedures that had to be followed by all those inside the terrestrial, air and sea borders, in order of preventing the spread of the SARS-CoV-2. Those measures were applied, in a paticular manner, even for the shipping industry. The state of emergency was ended by a similar Military Ordinance, which announced the state of alert in Romania, starting with 14 May [3].

\section{PORT OF CONSTANTA}

The Port of Constanta (Fig. 1) represents one of the largest and most important port in the Black Sea, being also included in the top 20 in Europe $[4,5]$. The importance of the port of Constanta implies, to a 
large extent, its geographical position. Constanta is situated on the North West coast of the Black Sea, at approximately 180 miles far from Bosporus Strait. It self, by the Danube-Black Sea Channel, the Port of Constanta represents a gate to the inland navigation to Central Europe. It occupies an area of 3,926 ha, of which $1 / 3$ representing land and $2 / 3$ water [6]. All these advantages together with the facilities, which the port makes available to shipowners, transform the port of Constanta into a very busy port. This aspect also results from the trend that can be deduced from the official statistics that the port management makes public annually. This trend shows a considerable increase, in the last 3 years, of the volume of goods handled in the port, but also in the number of port calls. At the same time, the Port of Constanta is on the route to important Ukrainian ports or to the Maritime Danube, this aspect giving it prospects to win port calls and not only for bunkering services.

Previous studies [5, 7] have shown that, in the atmosphere, every hour, it is spread between 2 tons and 2.5 tons of SOx, 1-1.5 tons NOx and about $12 \mathrm{~kg}$ of PM10 only from the Constanta harbour activities. On the other hand, the quality of the air in the Port of Constanta can be influenced also by the ships that are operating near the Romanian Coast, as offshore dedicated vessels [8]. In a smaller measure, but not negligible, due to dominant direction of the wind (as can be noticed from Figure 3), the ships that are on routes to Ukrainian ports or the ones intending to enter on Sulina Channel (Danube) can also have a contribution on the air quality near Constanta harbour.

On the other hand, the quality of the air in the Port of Constanta can also be influenced by the ships, which are operating near the Romanian Coast, the statement being from other studies related to the present subject $[8,10-13]$. The statement that the shipping is influencing the concentrations of air components in the natural atmosphere is a real concern in many scientific studies, in a lot of political reports. Undoubtedly, anthropogenic activities carried out for economic purposes, of industrial type, create concentrations of pollutants in the vicinity of their development, which change the natural state of the percentage in which these chemical compounds are naturally found in the terrestrial atmospheric air.

\section{QUALITY AIR PARAMETERS}

The air quality data parameters were provided by the web site calitateaer.ro, a public database entitled The National Air Quality Monitoring Network, subordinated to the Ministry of the Environment Romania [14]. In Figure 1, the monitoring fix stations (CT2 and CT5) can be identified, which are situated in the proximity of Constanta harbour. In this study, only the CT2 data parameters were used, because CT5 data from the periods choose for the study were incomplete and the available data did not have an overlapping period.

In general, the quality of the air is given by a series of parameters, a part of them being shown in Fig. 2: Carbon oxides, Sulphur oxides, Nitrogen monoxide, particle matter, etc. All these parameters should be analyzed in a study which intends to determine the air quality in a particular moment or period of time $[15,16]$.

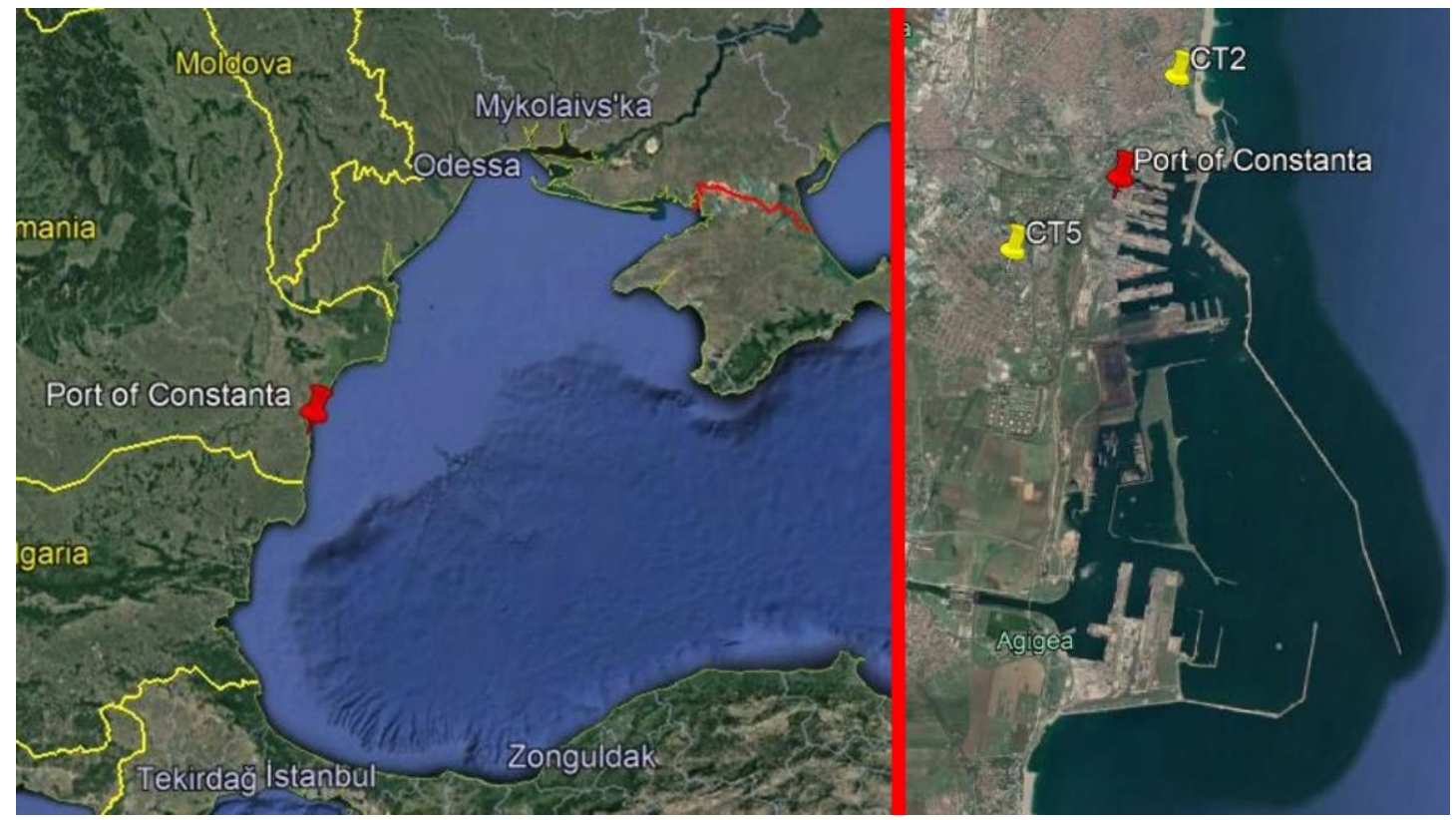

Fig.1. Port of Constanta location/ monitoring fix stations (CT2, CT5) identification [9] 


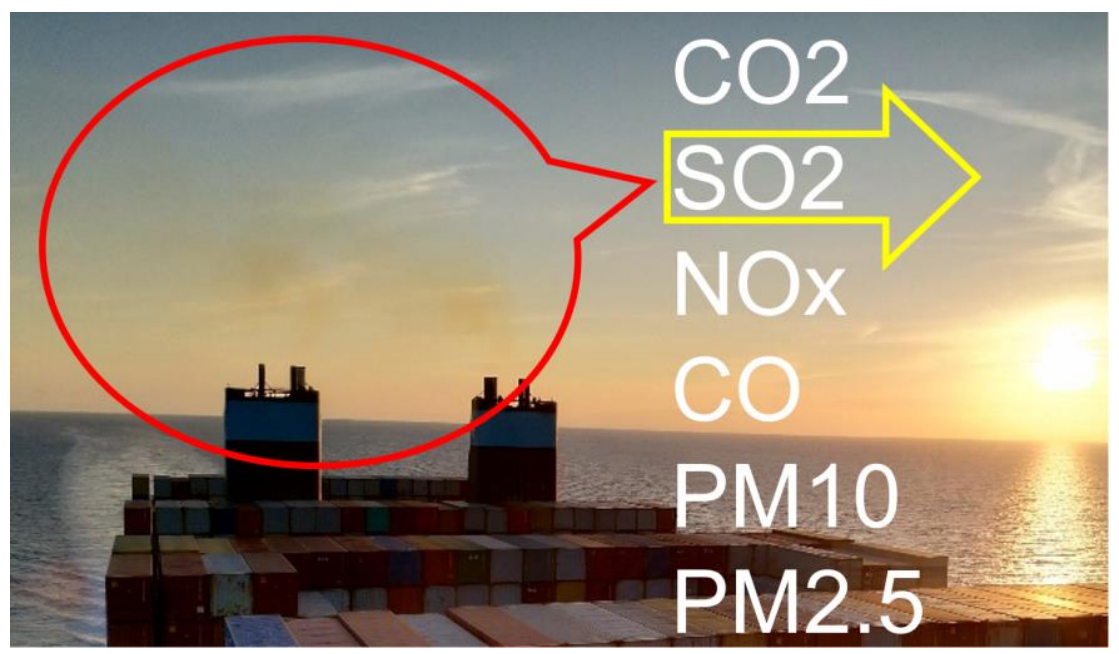

Fig. 2. Emissions generated by ships through their funnel

The present study is trying to determine the link with the vessel emissions. In this sense, it was considered that the daily evolution of the parameter SO2 should be analyzed, this being able to show the link between vessel emissions and the quality of the air in Constanta. The SO2 was chosen taking into account that it represents a good benchmark for emissions resulted from shipping [1]. This study tried to get out of the equation the impact that industry or, for example, road traffic could have had. Using the presented methodology, this cannot be done, but an attempt was done to reduce the effect by identifying a parameter that is much more relevant for shipping than for other anthropogenic activities that could create air emissions [17]. In the state of emergency period, according with some press reports, the road traffic shown a decreasing of $41 \%$ [18]. Under these conditions, it could not have been considered as a viable parameter: $\mathrm{CO}, \mathrm{CO} 2, \mathrm{NOx}$ or $\mathrm{PM}$, because each one is a very important result of pollution of terrestrial activities.

The state of emergency in Romania was officially declared by the Romanian Government between 18 March till 14 May. Those two dates are indicated in Figure 3, with a vertical black line for each of it. Thus, it was chosen as a period of investigation $1^{\text {st }}$ March-31 May 2020 [3]. In order to be able to detect more clearly if something completely different happened, it was used a comparison to historical data, data being identified for a similar period of 2019.

In the present study, it was considered necessary a buffer period, before and after the state of emergency, for analyzing the effect of SARS-CoV-2 virus. Nevertheless, for the quality air parameters, the period between 18 March till 14 May 2020 was taken into consideration. The first buffer period began on $1^{\text {st }}$ March and has continued till 17 March, this period of time preceding the state of emergency in Romania. The second buffer period began on 15 May and has continued till the end of May.

The red line with green points represents the daily values of SO2, in the year 2020. In the same time, the blue line represents the daily values of $\mathrm{SO} 2$ for a similar period in 2019.

For a better understanding, there was created a polynomial trend for each period every year. Now, it can be observed in Fig. 3 the pointed pink line representing the trends according to the data from 2020 of the selected period. The 2020 trend line is shown for 31 May, compared to 1 March, in the same year, a $30 \%$ decreasing of sulphur dioxide emissions.

In the same manner, a quick evaluation was done for the same period of 2019.

From the comparative perspective of data from 2020 and 2019, it is not resulting that the governmental measures taken because of COVID-19, did some unnatural discrepancies. The 2019 trend has a similar decreasing direction, instead the angle was bigger, so it can be found a difference between the min and the max bigger than $70 \%$.

As the first reaction, attributed to the information that the factories in China would have stopped their activity and that this would have as effect delays in the delivery of goods to Europe, this presumption would have been a wrong hypothesis, namely to believe that the maritime traffic decreased in volume in the Port of Constanta. The most recent statistics from the Port of Constanta presented an increasing of $3.31 \%$ for the first four months of 2020, in comparison to the previous year, of the tonnage of operated goods. On the other hand, the number of vessels which called the harbour services were 4450 
in the first four months in $2020(+6.7 \%)$, instead of 4152 in 2019 [19].

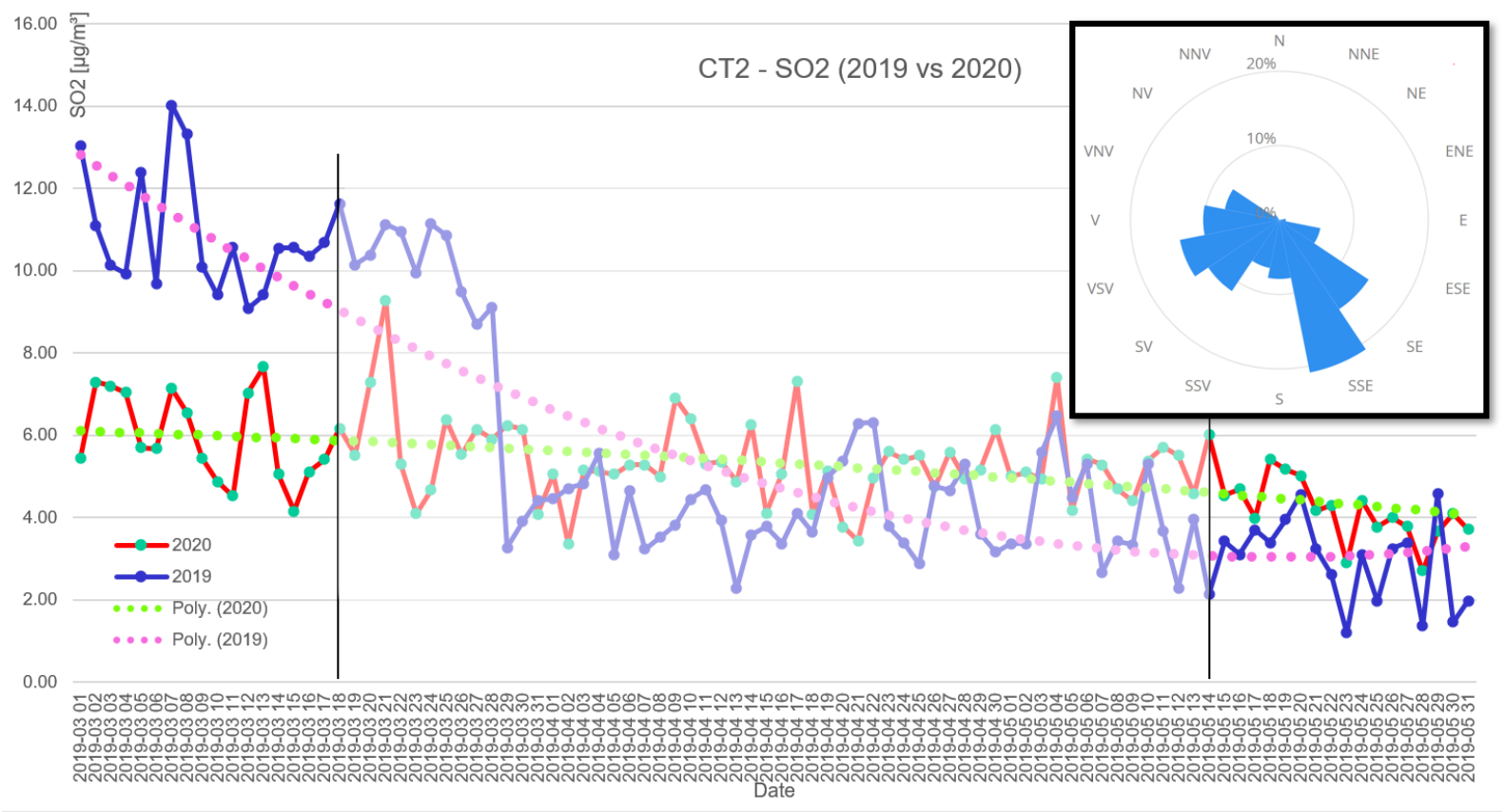

Fig. 3. Sulphur dioxides emissions in CT2, evaluated between $1^{\text {st }}$ March and 31 May, for 2020 and 2019

Taking into account the dominant direction of air currents, which emerges from Figure 3 as a recommendation for future studies, but not only, it is considered appropriate to install a mobile or fixed monitoring station in the South East area of Constanta harbour. The recommendation for the location of such an air sampling point would be the area of Agigea locality. Following this recommendation, it will be possible to collect and analyze much more relevant data on air quality and the effects of activities in the port area.

To conclude, the trend line which is a descending one in 2020, can be influenced by the SARS-CoV-2 measures which were taken by the Government. In this case, it should be studied which were the descending reasons for the 2019 similar period.

\section{CONCLUSIONS}

In general, the marine diesel engines/generators are producing significant emissions of carbon oxides $(\mathrm{CO} 2, \mathrm{CO})$, Sulphur dioxide (SO2), fine particulate matter (PM2.5 and PM10), Nitrogen oxides (NOx) [20-21], as represented in Figure 2. In the context of COVID-19, was chosen to investigate the SO2, because this parameter is most relevant for the shipping industry. Because of governmental measures which were taken in the state emergency period the road traffic was decreasing as an average of $41 \%$, which reasonably affect the rest of parameters. This scenario was chosen in order to obtain more relevant results.

The results are not exactly conclusive, but they show that the state of the emergency period has positively affected air quality. Due to the decreasing tendency of air pollutants. Analyzing the available data seems that in the case of sulfur dioxide in the air the percentage decreased by $30 \%$.

However, there are two major doubts, one of them about how the network of fixed monitoring stations is positioned. Where, due to the dominant wind direction in that geographical area, the actual effects of the port area do not appear to be recorded correctly.

The second being the trend that proved to be identical in action and much steeper in terms of the size of the daily values of pollutants composed of Sulfur, from the similar period of the previous year, which was used as a benchmark for results validation and verification in this study.

The period was too short to agree to the fact that world trade was affected by an economic crisis. A real decreasing of pollutant agents due to COVID-19 is expected to appear in the next period, at the global level by "slow steaming" phenomena. The slow steaming practices were highlighted and naturally adopted in the economic crisis 2009-2012. It is expected to appear also in the next period, more probably in the context of the expected economic crisis as "post-pandemic" response. 
As future research directions, it is imperative to understand what happened between March 1 and May 31,2019 in order to be able to conclude correctly both about the targeted period in the present study but also for the one in 2019. It is also interesting to follow how things have evolved regarding the polluting compounds after the appeared relaxation measures, after May 15, 2020. If a similar situation of reimposing the state of emergency in Romania is reached, it will be necessary to perform a new analysis regarding this subject, by comparing the daily values of air polluting compounds, for the two contexts.

\section{ACKNOWLEDGEMENT}

This work was carried out on the project ANTREPRENORDOC in the framework of Human Resources Development Operational Program 20142020, financed from the European Social Fund under the contract number 36355/23.05.2019 HRDOP/380/6/13 - SMIS Code: 123847.

\section{REFERENCES}

[1] Merk O., 2014, Shipping emissions in ports. Available online: https://www.itf-oecd.org/ sites/default/files/docs/dp201420.pdf (accessed in May 2020).

[2] Energy efficeincy in transport. Available online: https://en.wikipedia.org/wiki/Energy_ efficiency_in_transport (accessed in June 2020).

[3] Military Ordinances. Available online: https://www.mai.gov.ro/ (accessed in July 2020).

[4] Maritime transport statistics - short sea shipping of goods. Available online: https://ec.europa. eu/eurostat/statistics explained/index.php/Maritime_ transport_statistics_sshort_sea_shipping_of_Goods (accessed in May 2020).

[5] Rata V., Rusu E., 2020, Can Air Quality be Influenced in Coastal Areas by Shipping?, Journal of Marine Science, 2(1), pp. 17-22.

[6] Port of Constanta. Available online: https://en.wikipedia.org/wiki/Port_of_Constan\%C8\% 9Ba (accessed in June 2020).

[7] Rata V., Rusu L., 2019, Air pollutant products resulting from port activity of ships in Constanta harbour, Proceeding of SGEM Albena 2019 Conference. doi: 10.5593/sgem2019/4.1/S19.104, pp 821-828.

[8] Rata V., Rusu L., 2020, Impact on Air Quality of the Offshore-Ships Operating in the Black Sea Maritime Borders of Romania, Journal of Environmental Protection and Ecology, 21(1), pp. 19-27.

[9] Google Earth Application

[10] Impacts of Shipping on UK Air Quality, 2017. Available online: https:/ukair.defra.gov.uk/assets/ documents/reports/cat11/1708081025_170807_Shipp ing_Report.pdf (accessed in June 2020).
[11] Eyring A. V., Kohler H. W., Aardenne J., Lauer A., 2005, Emissions from international shipping: 1. The last 50 years, Journal of Geophysical Research, , 110:D17305. doi: 10.1029/2004JD005619

[12] Rata V., Hobjila A., Rusu L. 2019, LNG to Power in the Romanian port of Constanta, E3S Web of Conferences 103, 01007, ICACER 2019, pp. 1-5

[13] Langhella G., Iodice P., Amoresano A., Senatore A., 2016, Ship engines and air pollutants: emissions during fuel change-over and dispersion over coastal areas. Int. J Energy Environ Eng, 7, pp. 307-320.

[14] National Air Quality Monitoring Network (RO). Available online: http://calitateaer.ro/ (accessed in May 2020).

[15] Constantin D.E., Voiculescu M., Georgescu L., 2013. Satellite Observations Of No2 Trend Over Romania, The Scientific World Journal, Volume 2013, Article ID 261634, 10 pages, http://dx.doi.org/10.1155/2013/261634.

[16] Dragomir C.M., Constantin D.E., Voiculescu M., Georgescu L.P., Merlaud A., Van Roozendael M., 2015. Modeling results of atmospheric dispersion of $\mathrm{NO}_{2}$ in an urban area using METI-LIS and comparison with coincident mobile DOAS measurements, Atmospheric Pollution Research 3, 503-510, doi: 10.5094/APR.2015.056.

[17] Gasparotti C., 2015, The influence of the anthropic factors on the black sea state, Mechanical Testing and Diagnosis, (V) 1, pp. 13-31.

[18] Hotnews.ro. Available online: https://www.hotnews.ro/stiri-administratie_locala23991382-studiu-perioada-starii-urgenta-traficul-dinbucuresti-scazut-medie-36-zilele-munca-54-

weekend-dar-izolat-fost-scaderi-70.htm (accessed in May 2020).

[19] Freight traffic in Romanian seaports, increasing at the beginning of 2020 (RO). Available online: https://www.portofconstantza.com/pn/ro/stire/1/0/17 655 (accessed in May 2020).

[20] Ljevaja D., 2011, Impact of emissions of marine diesel engines to air pollution on the example of the Yougoslav river shipping, Proceeding of IJTTE 2011 Conference, 1(3), pp:149-157.

[21] Boersma K. F., Vinken G. C. M., Tournadre J., 2015, Ships going slow in reducing their NOx emissions: changes in 2005-2012 ship exhaust inferred from satellite measurements over Europe, Environmental Research Letters, 10(7). doi.org/10.1088/1748-9326/10/7/074007

[22] Campling P., Janssen L., Vanherle K., Cofala J., Heyes C., Sander R., 2013, Specific evaluation of emissions from shipping including assessment for the establishment of possible new emission control areas in European Seas. Available on line https://ec.europa.eu/environment/air/pdf/Main\%20Re port\%20Shipping.pdf (accessed in October 2020). 